JOURNAL OF SECURITY AND SUSTAINABILITY ISSUES

ISSN 2029-7017 print/ISSN 2029-7025 online

2021 Volume 11

https://doi.org/10.47459/jssi.2021.11.46

\title{
SECURITY OF MASS EVENTS AND THEIR PROTECTION AGAINST TERRORIST ACTIVITIES
}

\author{
Marlena Lorek ${ }^{1}$, Anna Pięta-Szawara ${ }^{2}$ \\ ${ }^{1}$ Rzeszów University of Technology, Aleja Powstańców Warszawy 12, 35-959 Rzeszów, Poland \\ ${ }^{2}$ Uniwersity of Rzeszow, aleja Tadeusza Rejtana 16C, 35-310 Rzeszów, Poland \\ E-mails:1'mlorek@prz.edu.pl; $2 a p i e t a @ u r . e d u . p l$
}

Received 18 July 2021; accepted 12 October 2021; published 30 December 2021

\begin{abstract}
The subject of this article concerns the safety of mass events and is dictated by their increasing popularity. Mass events are organized at various levels of the territorial division and have a very diverse range. Their safe organization and course are important from the point of view of the country's internal security. The authors provide novel insights into risk management peculiarities of mass events in designed to prevent possible terrorist activities.
\end{abstract}

Keywords: security; mass events; terrorism; risk management

Reference to this paper should be made as follows: Lorek, M., Pięta-Szawara, A. 2021. Security of mass events and their protection against terrorist activities. Journal of Security and Sustainability Issues, 11, 509-516. https://doi.org/10.47459/jssi.2021.11.46

JEL Classifications: I12

Additional disciplines: security and safety

\section{Introduction}

Safety is the most important need of an every citizen of our country, therefore the organization of various public gatherings, such as concerts, football matches or other matches in closed or open-air areas, must be secured and free from threats that may occur during its duration. In the era of globalization, it is the most important that all participants are able to be fully responsible and want to comply with the relevant procedures or regulations in force in a given space where a mass assembly is organized. Moreover, the greatest contemporary threat that can be encountered in the presence of such a large group of people in one place is all kinds of terrorist attacks that can be carried out using various types of weapons. According to S. Koziej, "the theater of war against contemporary terrorism is practically the whole world. But this theater has special scenes. They include all large clusters of people, such as mass events are usually organized in large urban agglomerations" (Koziej 2012).

Planning and securing a mass event is a real organizational challenge. It is a series of coordinated activities that include ensuring the safety of both participants and viewers. The organizer is directly responsible for this safety, but the obligations of security rests with the commune head, mayor, city president and voivode. In addition, the obligation rests with uniformed services, such as: the Police, Fire Brigade and other units for fire protection, i.e. Volunteer Fire Brigades and Medical Services. In the event of threats that require protection in a given area, other services responsible for order in a given area may be appointed (MEN 2021).

This article focuses on the presentation of the issue of ensuring safety during mass events. 


\section{Definition of mass events}

Pursuant to Art. 3 of the Act of March 20, 2009 (Journal of Laws 2009, No. 62, item 504), a mass event is a mass artistic and entertainment event, mass sports event, including a football match, except for the following events:

- organized in theaters, operas, operettas, philharmonics, cinemas, museums, libraries, community centers and art galleries or other similar venues,

- organized in schools and educational institutions by the managers of these schools and institutions,

- organized as a part of sports competition between children and youth,

- sports organized for disabled athletes,

- general sport of physical recreation character, open to the public and free of charge, organized in an open area,

- closed ones organized by employers for their employees, if the type of event corresponds to the purpose of the facility or area where it is to be held.

An artistic and entertainment event will be an artistic or entertainment event to be held in the following venues (Art. 3 ust. 2 ustawy z 20 marca 2009 r.):

- at the stadium, in another facility that is not a building, or in the area enabling the conduct of a mass event, where the number of places provided by the organizer for people, determined in accordance with the provisions of the construction law and fire protection regulations, is not less than 1000

- in a sports hall or other building enabling a mass event, in which the number of places made available by the organizer for people, determined in accordance with the provisions of the construction law and fire protection regulations, is not less than 500 .

The most popular forms of mass events are sports events. They should be understood as sports events organized for the purpose of sports competition or popularization of physical culture, which take place at:

- a stadium or other facility that is not a building, where the number of places provided by the organizer for people, in accordance with the provisions of the construction law and fire protection regulations, is not less than 1000, and in the case of a sports hall or other building enabling a mass event - not less than 300 ,

- an area enabling a mass event, where the number of places made available by the organizer for people is not less than 1000 (Jurgilewicz, 2021).

The safety of a mass spectacle "consists in meeting by its organizers the requirements in the field of safety of people participating in the event, public order protection, medical security, and ensuring the appropriate technical condition of buildings together with technical installations and devices, in particular fire and sanitary facilities (Article 5 (2) (Suski, 2010).

\section{Reasons for choosing mass events as the sites of terrorist attacks}

The dynamic changes that occur in the globalized security environment (national and international) are characterized by increasing indeterminacy. This is supported by the challenges and threats changing over time, the emergence of new entities of international law, progressing asymmetry and visible privatization of armed conflicts" (Żebrowski, 2010).

The globalized reality in which contemporary social processes are immersed, is becoming a subsoil on which contemporary asymmetric conflicts develop. "The subject of an asymmetric war does not have to be the state, but basically any organized group of people (political, religious, criminal, ideological, ecological) linked by specific goals. Asymmetric struggle does not know the concept of the battlefield, the front, it takes place in dispersion, without maintaining geographical and chronological continuity. A party engaging in an asymmetric war uses every available tool to achieve its intended goal. The methods of combat can be assassination, street demonstrations, media campaigns, the spread of poisonous substances by mail or water supply, provoking a campaign 
of international pressure, destroying places of symbolic importance or manipulating stock prices on the stock exchange. The essence of asymmetry in this case consists in the actual lack of a tangent point between the war efforts of both sides - conventional armed forces, even equipped with the most modern equipment, are not able to effectively oppose the action of, for example, mass hijacking of passenger planes by suicides"(Piątkowski 2002).

Terrorism is a phenomenon that destabilizes the internal situation of virtually every country. The background of terrorism is very diverse. There are conflicting phenomena that affect national and international security:

- independence aspirations of religious and ethnic groups,

- dissatisfaction with the development of the internal situation,

- reviving chauvinism and nationalism,

- progressive differences in the standard of living of societies,

- economic, technical and financial dependence.

Mutual clash of the aspirations of people, social groups and states means that very often their goals turn out to be contradictory, which inevitably leads to conflict situations that may be a source of threats to security. Mass events are chosen by bombers for many reasons, including such(Aleksandrowicz 2011):

- a rescue operation conducted in such conditions is difficult and exposed to many wrong decisions, which may additionally increase the number of victims,

- the mood of joy of the participants of a mass event makes them less cautious,

- the presence of VIPs raises the rank of the attack, its spectacularity,

- open events that accompany the games are also a problem - attacks can occur in markets, pubs, where games are watched on large screens and televisions, but also in means of transport - at airports, on trains, buses (the so-called soft goals),

- before the attack, the nature of the mass event gives the bombers an advantage - no one with a backpack will seem suspicious,

- live coverage of mass events at which the attack was carried out increases its impact on society, its effect,

- there are hundreds or thousands of people at the site of a mass event, which translates into an attack on a huge number of victims,

- the bomber remains anonymous in the crowd, he can easily escape and blend in with the crowd,

- simple panic may, as an effect or as an additional effect of the attack, lead to the trampling of many participants of mass events.

\section{Counteracting security attacks during mass events}

Ensuring safety during the mass event on the part of the organizer includes (Parszowski, Kruczyński, 2015):

- meeting the requirements set out in the construction law, sanitary and fire protection regulations,

- designation of evacuation routes,

- designation of a place for security management services,

- ensuring communication,

- provision of appropriate rescue and firefighting equipment,

- providing medical assistance,

- ensuring the participation of information and order services and the safety manager,

- providing hygienic and sanitary facilities.

Security threats during mass events are in many cases caused by the human factor (Sienkiewicz 2009):

- lack of appropriate qualifications,

- insufficient training of services responsible for security,

- ignorance of basic procedures. 
"Asymmetric strategies reflect the strategies consistently used by the weak against the strong, focusing on inflicting suffering rather than winning battles, gaining time rather than striving to engage, targeting both the enemy's political base in his country and his military ability at the front," taking advantage of his intolerance of losses and weaker motivation for a decisive end to the conflict, as well as playing on his reluctance to cause casualties on the civilian side, even if military options are available. In short, while militarily stronger powers naturally prefer decisive victories on the battlefield, the weaker ones show a readiness to drag the civil sphere into the vortex of conflict, while avoiding open combat" (Parszowski, Kruczyński, 2015).

In the context of mass events, objects vulnerable to terrorist attacks should be identified (see Table 1).

Table 1. Objects vulnerable to terrorist attacks.

\begin{tabular}{|c|l|}
\hline No. & \multicolumn{1}{|c|}{ Objects vulnerable to terrorist attacks } \\
\hline 1. & $\begin{array}{l}\text { state administration (parliament, ministries ensuring the continuity of government operations, state security services, crisis } \\
\text { management centers, emergency services, etc.) }\end{array}$ \\
\hline 2. & banking and finance \\
\hline 3. & energy (gas, oil, liquid fuels, power plants and mining, processing and distribution infrastructure) \\
\hline 4. & $\begin{array}{l}\text { key resources (shopping malls, office buildings, stadiums - arenas and other sports facilities, amusement parks, cinemas, theaters, } \\
\text { school buildings, tourism industry) }\end{array}$ \\
\hline 5. & persons holding the highest positions in the state \\
\hline 6. & $\begin{array}{l}\text { industry important for the economy (heavy industry, production and storage of hazardous substances - chemical, biological, } \\
\text { nuclear, radiological, storage of hazardous waste, defense industry) }\end{array}$ \\
\hline 7. & national symbols (buildings, monuments and museums of national importance, sports facilities) \\
\hline 8. & ICT systems and technology, communications and ICT \\
\hline 9. & transport (road, rail, water and air together with control and safety systems) \\
\hline 10. & water (extraction, purification, storage, distribution) \\
\hline 11. & justice (judiciary and justice) \\
\hline 12. & health (hospitals, public health, blood storage stations, pharmaceutical industry) \\
\hline 13. & food (production, storage and distribution) \\
\hline
\end{tabular}

Source: developed on the basis of the Act of April 26, 2007 on crisis management (Journal of Laws No. 89, item 590, as amended).

In the aspect of considerations regarding the organization and course of mass events, the following categories of threats can be identified:

- attacks from cyberspace,

- physical attacks on objects,

- risks related to the operation of infrastructure,

- risks related to the number of participants,

- threats related to the adopted infrastructure design solutions and architecture,

- risks related to infrastructure safety management.

The fight against terrorism consists of four basic stages (Białek, 2005):

- prophylaxis,

- prevention,

- reaction,

- prosecution.

Prevention includes activities based on strategic analysis. It is an attempt to predict events that may occur in the near or distant future. Such a projection of possible threats makes it possible to take all necessary steps in advance, which may eliminate the terrorist threat (Białek 2005). 
Prevention, on the other hand, is actions when the threat has already arisen. They are about preventing terrorist attacks. It is extremely important at this stage to react to the mere suspicion of planning an attack. The reaction is direct combat. It is a response to a terrorist act that has occurred. At this stage, there is a direct clash with terrorist forces, which may be associated with the use of weapons and the physical elimination of the bombers. Prosecution consists in administering justice, imposing a penalty. The perpetrators of the act should absolutely be caught and brought to criminal liability. The prosecution is also to protect against further terrorist attacks, the fear of the consequences may contribute to the abandonment of the attack (Duda, 2002; Safety of mass events, n.d.).

It is very important to prioritize and assess the sensitivity of facilities where mass events take place to the impact of terrorists. This is one of the main tasks and problems of people responsible for security. For this you should:

- protect information and data (network security); train, practice, conduct safety training for security services in order to increase their awareness and ability to react soberly in crisis situations,

- have information connectivity, continuous data exchange system; react and respond to potential threats inform staff and the public about threats,

- carry out a series of activities that will allow to identify potential threats (including a terrorist attack), and then to determine the probability of a given event, preventive measures and possible consequences,

- enable security checks to be carried out by teams of external experts,

- implement safety measures commensurate with the risks identified in the assessments.

Remedial measures are actions taken to reduce or eliminate one / several weaknesses in the infrastructure where mass events take place. These measures include:

- checks,

- software,

- procedures,

- hardware,

- technical systems.

Countermeasures are selected on the basis of their availability, performance, and reliability. You can count among these:

- data safety,

- physical security,

- network security,

- access control,

- security policy, including procedures,

- loss prevention,

- crisis and emergency management.

An important role in this respect is also played by risk management during mass events, which consists in monitoring and reducing the risk to the level acceptable by the person responsible for security. The risk management process consists of the following stages (Dennison 2004):

- understanding the activity performed,

- risk identification,

- risk analysis,

- risk scoring,

- risk prioritization,

- risk management and control. 
Risk management cannot be seen as a burden for a mass event organizer, but as a way of maximizing the available opportunities and reducing the likelihood of failure. Risk identification and management should apply to every person in the organization and be carried out by the management of the organization.

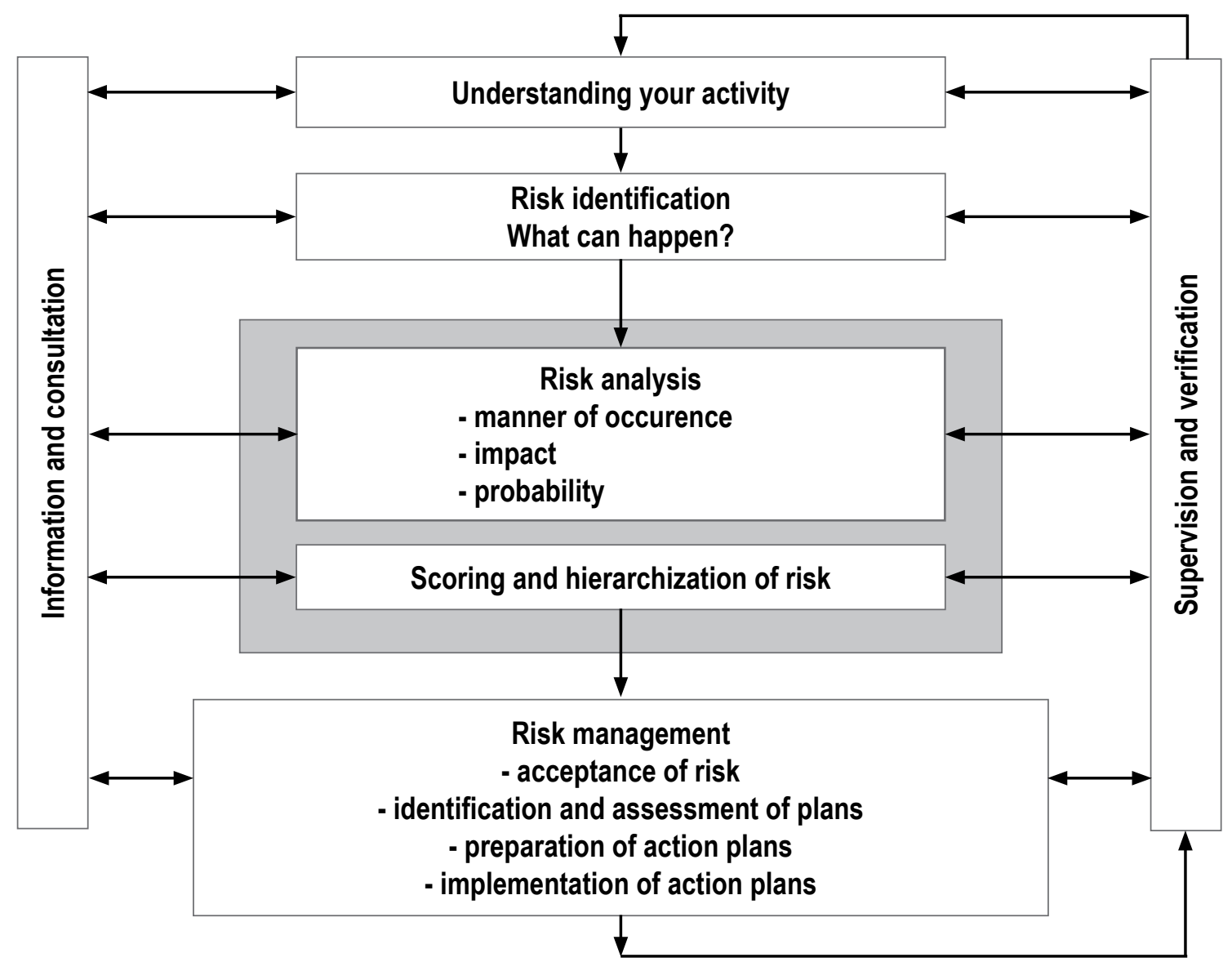

Figure 1. Relationships between the steps in the risk management process

Source: Z. Skwarek, Risk analysis, assessment and management in the civil-military protection system of Polish cities in the conditions of terrorist threats (Analiza i ocena oraz zarzadzanie ryzykiem $w$ systemie cywilno-wojskowej ochrony polskich miast w warunkach zagrożen terrorystycznych) [In:] Counteracting terrorist threats during mass events in the aspect of EURO 2012 (Przeciwdziatanie zagrożeniom terrorystycznym podczas imprez masowych w aspekcie EURO 2012), red. T. Bak, Konsorcjum Akademickie, Kraków-Rzeszów-Zamość 2012.

Figure 1 presents the mutual relations between the stages in the risk management process. Information and consultation as well as supervision and verification allow for the identification of the risk of a threat to the security of a mass event. Proper diagnosis enables the selection of adequate measures to prevent the emergence of undesirable situations. Risk management allows you to have control over it and eliminate possible threats.

The complex nature of the threats occurring during the organization and duration of mass events requires:

- the adequacy of the use of force in a specific situation,

- the advisability of combining specific actions of selected forces,

- integration of military and civil communication systems,

- unity of command, which comes down to subordinating forces to one person and agreeing tasks and determining the competence of coordination on the basis of cooperation,

- concentration of combined efforts in time and space,

- monitoring the development of the situation,

- gaining social acceptance and support for the legal (lawful) and justified and restrained (as appropriate to the situation) use of forces and means, 
- rational use of forces and resources in accordance with the tasks (situations) received,

- constant cooperation with the mass media and maintaining a specific information policy,

- risk assessment of actions taken and ensuring the maximum safety of the participating forces,

- ensuring great freedom of action resulting from obtaining rights, but also the obligation to take the necessary initiative.

Figure 2 shows a diagram of the risk management process in the process of ensuring safety during the organization and duration of mass events.

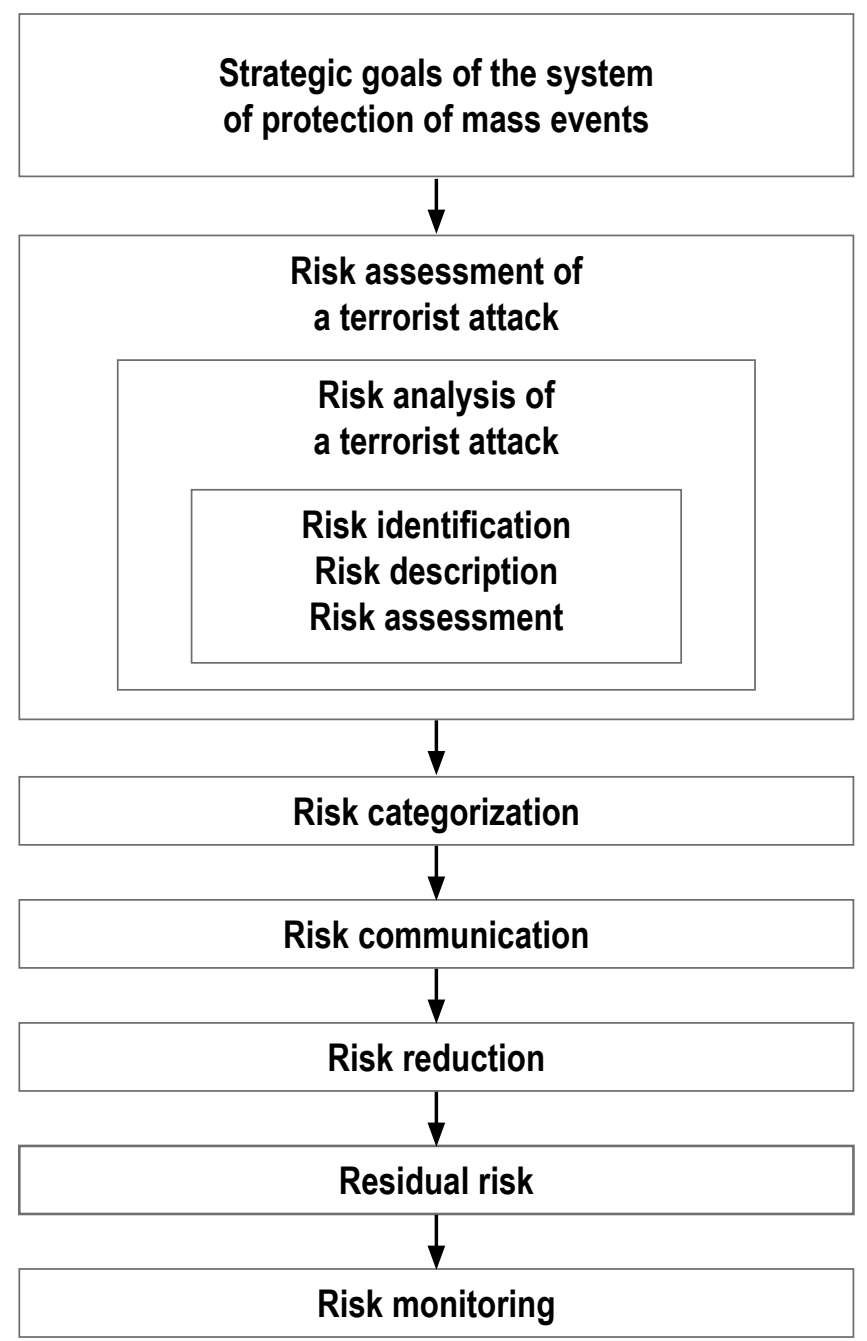

Figure 2. Risk management diagram in the process of ensuring safety in the organization process and during mass events.

Source: own study based on: J.R. Rak, Selected elements of risk management in a water company, "Environmental Protection" (Wybrane elementy zarzadzania ryzykiem w przedsiębiorstwie wodociagowym), "Ochrona Środowiska" 2007, nr 4.

The individual stages of the risk management scheme in the process of ensuring safety during the organization and duration of mass events allow for the identification of security threats and enable the implementation of procedures that will reduce the risk of undesirable phenomena to zero. In the context of recent events that have shocked not only Europe, but also the whole world, the assessment of the risk of a terrorist attack plays an important role in this scheme, which is why a separate module of the scheme has been devoted to this issue. Each mass event, where a larger number of people gather, can be a place of many threats that were not even foreseen in the basic scheme of action. Therefore, the organizer should secure resources and forces so that it is possible to evacuate the case without panic. 


\section{References:}

Act of April 26, 2007 on crisis management (Journal of Laws No. 89, item 590 as amended) (Ustawa z 26 kwietnia 2007 r. o zarządzaniu kryzysowym (Dz.U. nr 89, poz. 590 ze zm.).

Act of 20 March 2009 on the safety of mass events (Journal of Laws No. 62, item 504) Ustawa z 20 marca 2009 r. o bezpieczeństwie imprez masowych (Dz.U. nr 62, poz. 504).

Aleksandrowicz, T.R. 2011. Mass event as a target of a terrorist attack (Impreza masowa jako cel zamachu terrorystycznego) [w:] Security of the European Football Championship EURO 2012 (Bezpieczeństwo Mistrzostw Europy w Piłce Nożnej EURO 2012), red. K. Liedel, P. Piasecka, Difin, Warszawa.

Bezpieczeństwo imprez masowych (Safety of mass events) https://epodreczniki.pl/a/bezpieczenstwo-imprez-masowych/DYQ0E4y94

Białek, T. 2005. Terrorism - manipulation of fear (Terroryzm - manipulacja strachem), Studio Emka, Warszawa.

Dennison, B. 2004. Risk management in the public sector. A manual for the implementation of a risk management system in public administration in Poland (Zarzadzanie ryzykiem w sektorze publicznym. Podręcznik wdrożenia systemu zarzadzania ryzykiem w administracji publicznej w Polsce), Ministerstwo Finansów.

Duda, D. 2002. Islamic terrorism (Terroryzm islamski), Wyd. UJ, Kraków.

Jurgilewicz, M. 2021. (red.), Security of assemblies and mass events in Poland. Theory and practice (Bezpieczeństwo zgromadzeń $i$ imprez masowych w Polsce. Teoria i praktyka,), ASPRA, Warszawa.

Koziej, S. 2012. Terrorism and mass events in large urban agglomerations in the context of EURO 2012 (Terroryzm a imprezy masowe $w$ dużych aglomeracjach miejskich $w$ kontekście EURO 2012), www.koziej.pl/files/1216240767_terroryzm_a_euro_2012.doc

Parszowski, S., Kruczyński, A. 2015. Mass events, organization, security, good practices (Imprezy masowe, organizacja, bezpieczeństwo, dobre praktyki), Difin, Warszawa.

Piątkowski, K. 2002. Asymmetric war (Wojna asymetryczna), Komandos, 2(3)

Rak, J.R. 2007. Selected elements of risk management in a water company, „, Environmental Protection” (Wybrane elementy zarzadzania ryzykiem w przedsiębiorstwie wodociagowym, „Ochrona Środowiska”), 4.

Sienkiewicz, P., Górny, P., Świeboda, H. 2009. System aspects of safety management (Aspekty systemowe zarządzania bezpieczeństwem) [w:] Uniformed services in the EURO 2012 security system (Stużby mundurowe w systemie bezpieczeństwa EURO 2012), red. M. Marszałek, A. Glen, B. Wiśniewski, Prof-Art, Sieradz.

Skwarek, Z. 2012. Risk analysis, assessment and management in the civil-military protection system of Polish cities in the conditions of terrorist threats (Analiza i ocena oraz zarzadzanie ryzykiem w systemie cywilno-wojskowej ochrony polskich miast $w$ warunkach zagrożen terrorystycznych) [w:] Counteracting terrorist threats during mass events in the aspect of EURO 2012 (Przeciwdziałanie zagrożeniom terrorystycznym podczas imprez masowych $w$ aspekcie EURO 2012), red. T. Bak, Konsorcjum Akademickie, KrakówRzeszów-Zamość.

Suski, P. 2010. Meetings and mass events (Zgromadzenia i imprezy masowe), LexisNexis, Warszawa.

Żebrowski, A. 2010. 21st century intelligence and counterintelligence (Wywiad i kontrwywiad XXI wieku), Innovatio Press, Lublin.

Dr Marlena LOREK, Rzeszów University of Technology.

ORCID: 0000-0002-6814-8162.

Dr Anna PIEtTA-SZAWARA, University of Rzeszow.

ORCID: 0000-0002-7237-295X 